E Q U I L I B R I U M

2 ( 5 ) 2010

ISSN 1689-765X

Irena Kropsz

\title{
Financial Liquidity of the Horticultural Enterprise PPO Siechnice in Poland
}

Key words: enterprise, financial solvency, horticulture, Lower Silesia, Poland

\begin{abstract}
One of the key issues in evaluating the financial condition of a company is the analysis of assets in relation to the due indebtedness, i.e., short-term obligations. Liquidity ratios calculated in such a manner help in the drawing of conclusions on the liquidity of the enterprise and its ability to pay its short-term liabilities. This paper examines the financial liquidity in 2005-2007 of a horticultural enterprise, producing and selling food, based on information available in the balance sheet, income statement, and the cash flow statement, as published in the company's financial reports. The company was selected using the following criteria: location in Lower Silesia, Poland, in a municipal-rural commune, and operating in the agricultural-food sector. The study was based on business books of the examined company. The economic analysis involved mainly the financial liquidity ratios. Additionally, descriptive and comparative methods were used to characterize and interpret the results. The results of the study show that the company had a good financial situation and had no problems with payment of current obligations without waiting for accounts receivable or de-stocking. Additionally, liquidity analysis based on transfers from its operating activity showed that the obligations of the examined company could be covered by money obtained during its operating activities.
\end{abstract}

\section{INTRODUCTION}

The analysis of the financial reports is not a full financial analysis as it is limited to the evaluation of structural ratios calculated within individual groups or even total assets or liabilities, and it only serves to examine the basic trends among the analyzed assets and liabilities.

In order to draw comparisons and examine the effectiveness of the enterprise, efficient management requires derived information based on principle financial ratios. These ratios help interpret financial reports, provide insight into the company's economic operations and are the basis for effective planning. In 
particular, they are useful in the control of the current processes inside the company - they signal threats or help improve the management process (Dębski, 2005).

One of the more important issues that needs to be dealt with in short-term financial management is financial solvency. Financial liquidity can be understood in two ways. Firstly, it concerns the liquidity of assets, i.e., the ease with which individual assets can be sold without additional costs or without being below their market value. Secondly, financial liquidity may also mean the company's ability to regulate its obligations on time. There exists a strict relationship between the two types of solvency. If a company has enough highly liquid assets to pay for its current obligations, e.g., cash or marketable securities, then its financial liquidity is high (Suski-Borek, 2001).

Financial liquidity is connected with the notion of profitability. A controlled decrease in financial liquidity usually leads to increased profitability, as the company may increase its sales via the issue of trade credits, or limit bank credit at the expense of increased obligations from suppliers. However, a too deep decrease in liquidity may hinder due payment of obligations, decrease profitability and in the long-term lead to bankruptcy. Liquidity may be measured and analyzed on the basis of:

- state of current assets and current obligations at the beginning and the end of the reporting period - static system;

- cash flows in the reporting period - dynamic system (Suski-Borek, 2001)

This paper analyzes the liquidity of the selected horticultural enterprise based on the ratios describing the company's ability to cover its short-term obligations. It also analyzes the company's financial situation using the ratios of cash sufficiency and efficiency.

\section{Aim, RAnge And Methods of The STUdy}

The aim of the paper was to determine the financial liquidity of a selected horticultural company. The company, PPP Siechnice sp. z o. o., operating in the agricultural-food sector, was located in Siechnice, a town in the $\dot{S} w$. Katarzyna commune, Lower Silesia. The range of the study included the financial situation of the company with special attention paid to financial solvency. Source materials were collected from the archives of the Regional Court in Wroclaw, the Economic Department of the National Court Register, for a BA paper under my supervision at the Department of Economy and Management at the Wroclaw University of Environmental and Life Sciences (Smoła, 2009). The collected data came from the balances, income statements and cash flow statements for the years 2005-2007.

The company was selected in a purposive fashion (Hague, Morgan 2004) using the following criteria: location in the area of the $1^{\text {st }}$ Functional Region in 
Lower Silesia, municipal-rural commune and operating in the agricultural-food sector.

This study was performed using a document based method based on financial statements. It has a comprehensive character and used economic analysis with special attention paid to the analysis of financial solvency. Comparative and descriptive methods were also used (Stachak, 1997). The results of the study are presented in tables (Kopeć, 1983; Hague, Morgan 2004). Table 1 presents the list of the applied ratios in the evaluation of the financial liquidity of the examined company.

Table 1. Ratios used in the liquidity analysis of the examined company

\begin{tabular}{|c|c|}
\hline Name & Formula \\
\hline \multicolumn{2}{|c|}{ liquidity ratios } \\
\hline Current ratio ( $3^{\text {rd }}$ degree $)$ & Current asset /Short-term liabilities \\
\hline Quick ratio ( $2^{\text {nd }}$ degree $)$ & $\begin{array}{c}\text { Current asset }-(\text { inventory }+ \text { prepayments }) / \\
\text { Short-term liabilities }\end{array}$ \\
\hline Cash ratio ( $1^{\text {st }}$ degree $)$ & Cash/Short-term liabilities \\
\hline \multicolumn{2}{|c|}{ Cash sufficiency ratios } \\
\hline $\begin{array}{c}\text { operating cash flows for the coverage of } \\
\text { total liabilities }\end{array}$ & operating net cash flows / total liabilities \\
\hline $\begin{array}{l}\text { operating cash flows for the coverage of } \\
\text { long-term liabilities }\end{array}$ & operating net cash flows / long-term liabilities \\
\hline Total operating cash flows & $\begin{array}{c}\text { operating net cash flows / payment of long- } \\
\text { term liabilities }+ \text { dividend payout }+ \text { purchase } \\
\text { of fixed asset }\end{array}$ \\
\hline \multicolumn{2}{|c|}{ Cash efficiency ratios } \\
\hline Sale efficiency & operating net cash flows / net sale \\
\hline Profit efficiency & operating net cash flows /operating profit \\
\hline Asset efficiency & operating cash flows /mean asset value \\
\hline Current asset efficiency & operating cash flows /mean current asset value \\
\hline
\end{tabular}

Source: own, based on literature (Bednarski, 2007, Suski-Borek, 2001).

\section{Results}

The ratio analysis is based on the calculation of appropriate financial ratios and comparing them with a certain reference, either with the situation in the sector 
or with the long-term results obtained by the company, e.g., annually, over several years. The calculation of financial ratios requires information included in the balance and income statement, and also in cash flow statements (Dębski, 2005).

Financial liquidity in a company is evaluated by examining the relation between the current assets with various degrees of liquidity and short-term liabilities. Therefore, financial ratios are used to show different degrees of financial liquidity (Nowak, 2005). This study also analyzes the cash flow based on the ratios of solvency, cash sufficiency and cash efficiency of the selected enterprise.

The company PPO Siechnice Sp. z o.o. operates in the business of production and trade of food, and is located is a city of Siechnice, Lower Silesia. Currently, PPO Siechnice is a company with a predominance of private capital. From 1 July $1996,51 \%$ of the shares (exactly 95,270 shares) have been the property of (Wrocław Heating Plant) Zespół Elektrociepłowni Wrocławskich KOGENERACJA S.A. based in Wrocław, Poland. The remaining 49\% of shares $(91,534$ shares) are owned by the Minister of the Treasury. The company grounds cover an area of 24 ha, including 22 ha of greenhouses and 1 ha of plastic film greenhouses, in service at the end of 1998. The total area of warehouses for materials for production, product warehouses and cold stores is about 0.5 hectare.

The number of permanent employees is approximately 350 , with extra workers hired seasonally. Due to the seasonal nature of food production, the number of jobs decreases in winter months and increases during the harvest. The company has a regular group of highly skilled and specialized employees, including experienced manual workers. Low staff turnover creates a sense of stability which positively affects productivity. According to the Polish Classification of Business, the company operates in:

1. Growing vegetables, mushrooms, flowers and ornamental plants, and a horticultural nursery of ornamental and fruit plants,

2. Wholesale of fruit and vegetables, flowers and plants and other foods

3. Retail sales of fruit and vegetables, flowers, plants, seeds and fertilizers

4. Other retail sales to non-specialized stores, hotels and motels with restaurants

5. Water treatment for one's purposes

6. Water distribution

7. Distribution of heat (steam and hot water)

8. Sewage disposal

The analyzed company is one of the largest Polish producers of vegetables, top-quality tomatoes and cucumbers grown under cover. Vegetables are grown using modern soil-less hydroponic technology - in rock wool, expanded clay and coconut fiber. The company uses integrated plant protection based on biological protection. Chemical protection includes only intervention in compliance with the current program of plant protection. Tomato flowers are pollinated naturally by bumblebees. Production is carried out in accordance with GLOBALGAP 
standards. The main goal of this standard is the use of measures aimed at reducing the adverse impact of agriculture on the environment. For several years PPO Siechnice has also produced ornamental plants. Over one year, approximately 100 species are cultivated in an area of 1 ha. Plants are sold in the company's own retail outlets and leading supermarkets throughout the country and beyond. For 10 years it has also produced balcony flowers, flowering plants and seedlings. Seedlings come from licensed breeders from all over the world [www. pposiechnice.pl / siechnice.php].

The financial liquidity ratios describe the current asset, i.e., working capital, the basis of the current activity of the company. The ratios show the solvency of the company based on its ability to cover its obligations. The values of the liquidity ratios obtained in the analyzed period between 2005 and 2007 are presented in table 2.

The calculations show that the current ratio in 2007 was lower than in the initial year, but is included in the optimal range (1.2-2.0) given by various authors (Bednarski, 2007, Suski-Borek, 2001). The value of 1.2 indicates an ability to cover current obligations. Only in 2006 did this ratio decrease below the minimum optimal value, which might then have necessitated the selling of some assets to cover current obligations.

The quick ratio presented in Table 2 shows that the most liquid elements of the current assets should be slightly greater than current obligations. Maintaining this level allows the quick coverage of obligations, if necessary. In this study, this ratio was at a slightly lower level, never reaching the optimum value between 1.0 and 1.2. Only in 2005 did it reach a level above 1, which shows that the company had no problems with the coverage of short-term obligations, without reducing its inventory. The situation worsened in 2006 and 2007 as the quick ratio was ca. 0.6 , much lower than the required minimum. It might have necessitated the reduction of inventory.

Another important question in cash flow. Cash and cash equivalents should not be too high. An excess level of cash is not recommended because it should be used for investing. A too high value of the ratio, above 0.2 , indicates opportunity costs, a sign that the managers did not know how to use those resources which by themselves did not bring any profit. A too low value of this ratio however, below 0.1 , may be the reason for the liquidity loss. The need for coverage of current short-term obligations may disrupt the liquidity balance in a given reporting period. 
Table 2. Liquidity ratios

\begin{tabular}{|l|c|c|c|}
\hline \multirow{2}{*}{ Ratio } & \multicolumn{3}{|c|}{ Ratio value } \\
\cline { 2 - 4 } & 2005 & 2006 & 2007 \\
\hline Current ratio & 1.74 & 0.90 & 1.18 \\
\hline Quick ratio & 1.07 & 0.62 & 0.66 \\
\hline Cash ratio & 0.38 & 0.13 & 0.16 \\
\hline
\end{tabular}

Source: own calculations based on the company's financial statements.

The optimum cash ratio value is $0.1-0.2$. The values of cash ratio of the analyzed company in 2005-2007 show that the company could immediately cover its current obligations without waiting for the payment of accounts receivable, or selling inventory, should the need arise. The cash ratio decreased in comparison with 2005, which was advantageous for the company - a too high level of cash suggests ineffective management.

To sum up, the analysis of the basic liquidity ratios shows that the analyzed company maintained liquidity, the ability to cover current obligations. The changing value of the ratios show positive trends in the company's liquidity.

The financial situation of a company based on cash flows may also be reflected by financial ratios (Bednarski, 2007):

- cash sufficiency

- cash efficiency

A cash flow statement is a financial statement that shows how changes in balance sheet and income accounts affect cash and cash equivalents at the disposal of the company. It presents cash flows into and from the company, i.e., all the incomes and payments of a company, except those that concern the purchase and sale of financial resources (Nowak 2005). Bearing this in mind, this study also examines the financial situation of the selected company based on cash sufficiency and cash efficiency ratios which determine if the operating cash is sufficient to cover the various expenses and obligations of the company. Table 3 presents the value of cash sufficiency for the analyzed company.

Table 3. Cash flow sufficiency ratios

\begin{tabular}{|l|c|c|c|}
\hline \multirow{2}{*}{ Ratio } & \multicolumn{3}{|c|}{ Ratio value } \\
\cline { 2 - 5 } Operating cash flow for the coverage of total liabilities & 2005 & 2006 & 2007 \\
\hline Operating cash flow for the coverage of long-term liabilities & 0.46 & 0.11 & 0.07 \\
\hline Operating cash flow & 0.00 & 0.24 & 0.12 \\
\hline
\end{tabular}

Source: own calculations based on financial statements. 
The calculated value of cash sufficiency of the operating cash flow for covering total obligations indicates that the company could have had problems with the coverage of all obligations as the operating cash was not enough to cover all liabilities. The ratio was always below the optimum value of 1 . Moreover, its values show a downward trend in 2007 , which indicated the necessity of additional financial resources.

Another ratio showing the operating cash flow sufficiency for the coverage of long-term obligations at 0.24 in 2006 and 0.12 in 2007, also did not exceed 1. It means that the operating cash was not sufficient to cover long-term obligations and the company needed additional financial resources. The situation was similar to total obligations - long-term obligations, dividend payouts, and investment expenses. The operating activity in 2005 had covered the expenses. The subsequent years showed that the company needed other financial resources as the ratio was close to zero.

Another group of ratios which gave a certain picture of the financial situation are cash flow efficiency ratios, used for the examination of return on sale, return on assets, return on equity, and the outside capital profitability. These ratios can be applied as the basic ratios in the estimation of the realization of the strategic goals of a company - the increase of its value to a great extent depends on its profitability (Bień, 2008). Table 4 presents the values of cash flow efficiency in the analyzed period between 2005 and 2007.

The calculations of the return on sale presented in Table 4 show in 2005 and 2006 more than $5 \%$ of net sales turned into operating cash flow, and in 2007 only $3 \%$. It means that each 100 PLN of sales income generated over 5 PLN in 2005 and 2006, and only 3 PLN in 2007.

Table 4. Cash flow efficiency (\%)

\begin{tabular}{|l|c|c|c|}
\hline \multirow{2}{*}{ Ratio } & \multicolumn{3}{|c|}{ Ratio value } \\
\cline { 2 - 4 } & 2005 & 2006 & 2007 \\
\hline Return on sale & 5.63 & 5.25 & 3.05 \\
\hline Return on profit & 694.30 & 159.92 & 89.01 \\
\hline Return on assets & 8.28 & 6.44 & 3.56 \\
\hline Return on current assets & 32.10 & 27.60 & 15.43 \\
\hline
\end{tabular}

Source: own calculations based on the company's financial statements.

Return on profit describes whether the operating cash flow comes from the operating profit or other sources. Data from 2005 and 2006 show that the cash flow didn't come only from operating profit. Its highest value was reached in 2005 , at $694 \%$, and later decreased down to $160 \%$. Data and calculations for 2007 show that cash flow was generated by operating profit in $89 \%$. 
Another ratio, return on assets, shows the ability of total assets to generate net cash flow from the operating activity. The results show that the ability of the examined company to generate cash flow from operating activity decreased over the examined period. In 2005 assets generated more than $8 \%$ of cash flow from the operating activity, in 2006 almost $6.5 \%$ and in 2007 only $3.5 \%$

Return on current assets describes the ability of current assets to generate net cash from the operating activity. Analyzing the values of this ratio, it can be observed that the ability to generate cash from the operating activity also decreased over the examined period. In 2005 the current assets generated about 32\% cash from the operating activity, almost $28 \%$ in 2006 , the ratio decreased to about $15 \%$ in 2007.

\section{Conclusions}

The development of companies greatly depends on the value of their own and outside capital. The application and sources of capital are very significant in any enterprise as they influence the operating costs, the liquidity and in effect the speed with which products are provided to customers. The results of this study lead to the following conclusions:

1. The evaluation of current liquidity showed no problems with the coverage of current obligations, as the current ratio was within the recommended range. It also showed that the company did not freeze its resources in current assets (in inventory or accounts receivable).

2. In the final year, the quick ratio reached a much lower value than recommended, which could have resulted in the necessity of selling inventory to cover obligations.

3. The company maintained a correct level of cash and cash equivalents. A visible decrease in the cash ratio is a positive trend, as cash should not be excessively saved by the company but rather invested.

4. The ratios of operating cash flow sufficiency showed that the operating profit was not enough to cover all obligations. Therefore, the company used resources from investments and financial activities.

5. The return on sales showed that each 100 PLN of income generated more than 5 PLN in 2005 and 2006, and 3 PLN in 2007.

6 . The ability of total assets and current assets to generate cash flows the operating activity decreased in the studied period.

In conclusion, the analysis of the basic liquidity ratios and the cash sufficiency and efficiency ratios showed a generally good financial situation of the company. The company maintained financial liquidity and the ability to pay its current obligations, as indicated by the improving values of individual liquidity ratios over the 3 years of the study. Thanks to the good financial condition and 
the involvement of outside capital, the company improved its financial result and maintained its position in the market. It was capable of covering its current obligations to contractors and workers.

\title{
REFERENCES
}

Bednarski L., (2007), Analiza finansowa w przedsiębiorstwie, Wyd. PWN, Warsaw, 78-80, $165-166$.

Bień W., (2008), Zarzqdzanie finansami przedsiębiorstwa, Wyd. Difin, Warsaw, 99-101.

Dębski. W., (2005), Teoretyczne i praktyczne aspekty zarzqdzania finansami przedsiębiorstwa, Wyd. PWN, Warsaw, 77.

Hague N.P., Morgan C.A., (2004), Market Research in Practice, 81-96, 151-163.

Kopeć B., (1983). Metodyka badań ekonomicznych w gospodarstwach rolnych, Wrocław, 166-199 .

Nowak E., (2005), Analiza sprawozdań finansowych, Wyd. PWE, Warsaw, 130, 194.

Smoła P., (2009), Zewnętrzne źródła finansowania przedsiębiorstw, Rękopis pracy magisterskiej napisanej w Katedrze Ekonomii i Zarządzania, UP we Wrocławiu pod kierunkiem: Ireny Kropsz.

Stachak S., (1997), Wstęp do Metodologii Nauk Ekonomicznych, Wyd. Książka i Wiedza, Warsaw, 151-156-209 .

Suski-Borek G., (2001), Ocena ptynności finansowej w przedsiębiorstwa [w:] „Rachunkowość", no. 7, Wyd. Rachunkowość Sp. Zo.o., Warszawa, 428-433.

Www.pposiechnice.pl/siechnice.php. Charakterystyka podmiotu.

\section{OCENA PEYNNOŚCI FINANSOWEJ PRZEDSIĘBIORSTWA OGRODNICZEGO NA PRZYKŁADZIE PRZEDSIĘBIORSTWA PPO SIECHNICE}

\author{
Słowa kluczowe: przedsiębiorstwo, płynność finansowa, ogrodnictwo, Dolny Ślask, Polska
}

\begin{abstract}
Abstrakt: Jednym z podstawowych zagadnień oceny sytuacji finansowej przedsiębiorstwa jest analiza powiązań zasobów obrotowych ze zobowiązaniami wymagalnymi, tj. zobowiązaniami krótkoterminowymi. Obliczane wskaźniki płynności umożliwiają sformułowanie opinii o stopniu wypłacalności przedsiębiorstwa oraz o jego zdolności do bieżącego regulowania bieżących zobowiązań. Opracowanie dotyczy analizy płynności finansowej przedsiębiorstwa w latach 2005-2007 na podstawie zebranych informacji zawartych w bilansie, rachunku zysków i strat oraz rachunku przepływów pieniężnych. Celem przeprowadzonych badań była ocena płynności finansowej wybranego przedsiębiorstwa działającego w branży rolno-spożywczej. Materiały źródłowe uzyskano ze sprawozdań finansowych badanego przedsiębiorstwa. Dobór obiektu do badań został dokonany w sposób celowy, natomiast kryterium celu była siedziba firmy na terenie Dolnego Śląska, położenie w gminie miejsko-wiejskiej oraz działalność w branży rolnospożywczej. Badania zostały przeprowadzone metodą dokumentacyjną przy wykorzystaniu dokumentów księgowych przedsiębiorstwa. Do opracowania wyników wykorzystano metodę analizy ekonomicznej, głównie wskaźniki płynności finansowej do oceny wypłacalności podmiotu. Dodatkowo wykorzystano metodę opisową i porównawczą do charakterystyki i interpretacji wyników badań. Uzyskane w opracowaniu wyniki badań dotyczące analizy płynności finansowej wybranego przedsiębiorstwa ogrodniczego
\end{abstract}


wykazały, że przedsiębiorstwo ma dobrą sytuację finansową oraz nie posiada problemów ze spłatą swoich bieżących zobowiązań bez czekania na spłatę należności bądź upłynniania zapasów. Dodatkowo $\mathrm{z}$ analizy płynności finansowej opartej na przepływach z działalności operacyjnej wynika, że na pokrycie powstałych zobowiązań podmiotu wystarczają środki pieniężne wypracowane w przedsiębiorstwie tylko na działalności operacyjnej. 